\title{
Joanna Puppel
}

Uniwersytet im. Adama Mickiewicza w Poznaniu

\section{KOMUNIKACJA NIEWERBALNA W UJĘCIU TEORII WYMIANY SPOŁECZNEJ I TEORII WPŁYWU SPOŁECZNEGO}

\author{
SUMMARY \\ Nonverbal communication in terms of the Social Exchange Theory \\ and the Theory of Social Impact
}

This article presents the main assumptions of the Social Exchange Theory and the Theory of Social Impact. Both theories allow us to analyze the impact of communication acts on both the benefits and costs as well as on the intensity of the impact of a given human communicator on another member of an interaction setup in different social contexts. The discussion presented here allows us to formulate the rules governing nonverbal communication in terms of both of these theories. These rules, called here the principles of nonverbal communication, are graded in relation to the Principles of Interaction discussed in this article.

Key words: Nonverbal Communication, Social Exchange Theory, Social Impact Theory

\section{PEЗЮME}

\section{Невербальная коммуникация с точки зрения теории социального обмена} и теории социального влияния

В данной статье представлены главные постулаты теории социального обмена и теории социального влияния. Обе теории дают возможность анализа коммуникационных актов как со стороны выгод и потерь, так и со стороны интенсивности влияния одного коммуникатора на другого в социальном взаимодействии. Представленная здесь дискуссия дает возможность сформулировать правила, управляющие невербальной коммуникацией с точки зрения обеих теорий. Эти правила, называемые правилами невербальной коммуникации (ПНK/ZKN) являются иерархическими по отношению к правилам взаимодействия (ПИ/ZI), обсуждаемым в данной статье. 


\section{Wstęp}

Działania ludzkie są podejmowane $\mathrm{z}$ myślą o realizacji konkretnego celu. Można zatem przyjąć, że działania ludzkie podporządkowane są zasadzie celowości. Komunikacja niewerbalna, chociaż odbiega od świadomie generowanej komunikacji werbalnej (uczestniczy w aktach komunikacyjnych z większym udziałem samoświadomości u komunikatorów odnośnie tej ostatniej), podlega również zasadzie realizacji celu. Cel, w wypadku aktów komunikacji, stanowi najogólniej wymianę informacji jako formę wymiany społecznej, podlega też wpływom społecznym. W niniejszym artykule podejmuję próbę spojrzenia na komunikację niewerbalną jako element szerzej rozumianej wymiany społecznej i wpływu społecznego o charakterze celowościowym.

Zjawisko wymiany społecznej najpełniej ujmuje teoria wymiany społecznej (ang. Theory of Social Exchange) Homansa ${ }^{1}$ i Blaua $^{2}$. Teoria ta analizuje proces społeczny jako zjawisko podporządkowane zasadzie kosztów (ang. costs) i korzyści (ang. rewards) lub nagród i kar, jakie dana jednostka otrzymała lub spodziewa się otrzymać od partnera interakcji. Według tej teorii, wymiana społeczna (np. akt komunikacyjny) jest z natury czynnością wspólną, w której dwóch lub więcej aktorów komunikacyjnych usiłuje uzyskać korzyści większe aniżeli te, do których może dojść lub dochodzi samotnie. Wspólnotowość zadania różni się formami wymiany społecznej, jak również stopniem współzależności pomiędzy partnerami danej wymiany społecznej, np. aktu komunikacyjnego.

Teoria wymiany społecznej, w ramach której proponuję spojrzeć na komunikację niewerbalną, ma swe korzenie w antropologii strukturalnej ${ }^{3}$, psychologii behawioralnej ${ }^{4}$ i analizie ekonomicznej ${ }^{5}$. Dzisiejsze założenia nadają tej teorii bardziej humanistyczny sens. U Blaua ${ }^{6}$, na przykład, i innych przedstawicieli ${ }^{7}$ tej teorii, społeczny charakter wymiany odnosił się do uzyskiwania korzyści. W ramach aktów wymiany jednostki oferują sobie pomoc, radę czy akceptację. Wymiana społeczna uważana jest za serię wymian, które łączą się zarówno z ko-

\footnotetext{
G. Homans, Social behavior: its elementary forms, New York 1961 (1972).

P. Blau, Exchange and power in social life, New York 1964.

C. Levi-Strauss, The elementary structures of kinship, Boston 1969.

B. F. Skinner, Verbal behavior, Massachusetts 1957; A. Bandura, Social Learning Theory, New York 1977.

5 J. S. Mill, Principles of Political Economy with Some of their Applications to Social Philosophy, London 1848.

6 P. Blau, Exchange and power in social life, New York 1964.

7 H. H. Kelly, J. W. Thibaut, The social psychology of groups, New York 1959; H. H. Kelly, J. W. Thibaut, Interpersonal relationships, New York 1978; H. H. Kelly, Personal relationships: their structures and processes, Hillsdale 1979; R. M. Emerson, Social exchange theory, „American Sociological Review” 1976, $\mathrm{nr} 35,3$ s. 35-362.
} 
rzyściami (czyli nagrodami), jak i z kosztami (czyli karami) ponoszonymi przez jej uczestników. Jest to działanie wzajemne i wykonywane bez świadomej wiedzy negocjacji, także bez świadomości odnośnie tego, czy i kiedy dana korzyść zostanie odwzajemniona. W działaniu tym korzyściami (nagrodami) są te elementy interakcji, które są nacechowane pozytywnie (np. radość, miłość, lojalność, zadowolenie z siebie), natomiast kosztami są te elementy, które posiadają negatywną wartość dla danej jednostki biorącej udział w wymianie społecznej (np. napięcie, czas, energia czy uwaga).

Wymiana społeczna występuje w ramach procesu wzajemnej zależności, w której uczestnicy zależą od siebie celem osiągnięcia określonych zysków. Jednostki biorące udział w wymianie społecznej są motywowane do otrzymywania zysków, które stanowią dla nich jakąś wymierną wartość.

Z punktu widzenia wymiany społecznej analiza kosztów i korzyści stanowi podstawę zrozumienia interakcji społecznej i zakłada racjonalne podejście do utrzymywania związków społecznych ze strony samych uczestników interakcji. Należy przyjąć, że jednostki rozumieją koszty związane z transakcjami społecznymi i korzyści z nich płynące. Potrafią zatem ocenić, czy wzajemna wymiana przyniesie im tzw. zysk, czyli korzyści, potrafią też ocenić ewentualne koszty, które należy ponieść. Całość operacji sprowadzona może być do następującego ogólnego schematu wymiany społecznej:

Jeśli wymiana nie przynosi zysku, interakcja może zostać zawieszona lub zakończona; jeśli przynosi jednak zysk, może być kontynuowana.

Jednym słowem, ludzie uczestniczący w interakcji społecznej spodziewają się zyskać korzyści mniej więcej proporcjonalnie do poniesionych kosztów. Wymiana oznacza wzajemne dostarczanie sobie nagród, niekoniecznie jednak równocześnie. Sekwencyjność zachowań i nieraz bardzo odległe w czasie tzw. „regulowanie wkładów” (ang. „regulating input”) pozwalają na analizę wymiany pod kątem korzyści i kosztów także w dłuższych odcinkach czasowych. Główną ideą teorii wymiany społecznej, zaproponowanej przez amerykańskich socjologów, George’a Caspara Homansa ${ }^{8}$ i Petera Blaua ${ }^{9}$, jest wzajemność zachowań partnerów. Drugą właściwością tej teorii jest interdyscyplinarny charakter pojęć stosowanych do opisu zachowań społecznych, korzysta ona bowiem zarówno z elementów socjologii, psychologii, jak i ekonomii.

8 G. Homans, Social behavior...

9 P. Blau, Exchange and power... 


\section{Podstawowe założenia teorii wymiany społecznej}

Głównym założeniem teorii wymiany społecznej jest postulat zaangażowania każdej jednostki w interakcjach społecznych, czyli zachowaniach społecznych (np. aktach komunikacyjnych), uruchamianych na własne życzenie. Zachowania każdej jednostki społecznej w każdym społecznym kontekście możemy przedstawić za pomocą prostego równania, które w ramach tej teorii może przyjąć postać prawa zachowania społecznego o następującej treści:

\section{ZACHOWANIE (ZYSK) = NAGRODY INTERAKCJI - KOSZT(Y) INTERAKCJI}

gdzie 'zachowanie' to element zwiększający nagrody lub omijający koszty. Nagrodami natomiast są wszystkie te elementy danego zachowania, które zwiększają dalsze zachowania o charakterze interakcyjnym. Z kolei kosztami są wszystkie realne i otrzymane tzw. 'debety' (ang. „debits”) wynikające z zachowania.

Teoria wymiany społecznej zakłada, że ludzie oczekują nagród i dążą do unikania kar. Jest to zgodne z założeniem, iż zachowania ludzkie są motywowane przez wewnętrzny mechanizm potrzeb. Zakłada ona ponadto, że ludzie są jednostkami racjonalnymi, które poprzez swoje zaangażowanie w interakcję racjonalnie dążą do zwiększenia własnych zysków. Stąd też możemy stwierdzić, że teoria wymiany społecznej ma charakter jednocześnie przedmiotowy i introspekcyjny. Dzięki informacji, która jest ogólnie dostępna, uczestnicy interakcji kalkulują nagrody i koszty związane z utrzymaniem się w określonym związku interakcyjnym. Jeżeli jednak w danej interakcji nie ma elementów gratyfikujących, interlokutor może zdecydować się na wybór opcji, która jest najmniej dla niego kosztowna. Jednocześnie standardy, których ludzie używają do analizy kosztów i korzyści, zależą od czasu przeprowadzenia takiej analizy oraz stopnia zaangażowania danej osoby w interakcję. Nacisk położony jest również na ważność roli różnorodności środków (np. zaangażowanych $\mathrm{w}$ akcie komunikacyjnym) występujących w związkach interakcyjnych. Zatem to, co jedna osoba uważać może za nagrodę, inna może postrzegać jako poniesiony przez nią koszt (i vice versa).

Teoria wymiany społecznej Homansa ${ }^{10}$ zawiera się w pięciu głównych twierdzeniach, które stanowią jednocześnie wyraźne nawiązanie do podstawowych założeń doktryny behawioryzmu:

1. Twierdzenie odnośnie sukcesu (ang. success proposition). Twierdzenie to mówi, że z wszystkich działań (zachowań) przedsięwziętych przez daną

10 G. Homans, Social behavior... 
osobę działanie, które było dotychczas najczęściej nagradzane, tj. takie, które przyniosło najwięcej zysku, jest najbardziej prawdopodobnym kandydatem do ponowienia. Jednym słowem, ludzie wykonują częściej to, za co są chwaleni. W ramach doktryny behawioryzmu możemy tutaj mówić o pozytywnym wzmocnieniu bodźca.

2. TwIERDZENIE odnośnie BODźCA (ang. stimulus proposition). Twierdzenie to mówi, że jeżeli w przeszłości pojawienie się określonego bodźca lub szeregu bodźców stało się okazją do nagrodzenia działań danej jednostki, to im bardziej aktualny bodziec (aktualna sytuacja) podobny jest do tego, który miał miejsce w przeszłości, tym bardziej jest prawdopodobne, iż osoba ta wykona ponownie to działanie (lub działania) jednocześnie w sposób podobny do tego, za który została nagrodzona. W ramach doktryny behawioryzmu możemy tutaj mówić o pozytywnym wzmocnieniu bodźca.

3. Twierdzenie odnośnie wartości (ang. value proposition). Twierdzenie to mówi, że im bardziej wartościowy dla danej jednostki jest rezultat działań partnera (np. uczestniczącego w akcie komunikacyjnym), tym bardziej prawdopodobne jest to, że osoba ta częściej będzie wzorowała swe zachowanie na tych właśnie działaniach. Twierdzenie to opiera się na zasadzie: „Staram się robić to, co lubią inni, by oni robili z kolei to, co lubię ja”.

4. TWIERDZENIE odnośnie AGRESJI lub AKCEPTACJI (ang. aggression/approval proposition). Twierdzenie to mówi, że kiedy działania danej osoby nie przynoszą spodziewanych nagród lub nie otrzyma ona nieoczekiwanej kary, jest bardziej prawdopodobne, że jej działania będą mieć charakter bardziej agresywny i dynamiczny. Z kolei, jeżeli nastąpi nieoczekiwana nagroda, lub nie pojawi się spodziewana kara, wtedy działania danej jednostki mogą mieć charakter pozytywny, czyli mogą mieć charakter akceptacji danego działania.

5. TWIERDZENIE odnośnie RACJONALNości (ang. rationality proposition). Twierdzenie to mówi, że wybierając między alternatywnymi działaniami, dana osoba wybiera takie, w których wartość wyniku podwojona przez prawdopodobieństwo otrzymania oczekiwanego rezultatu (a więc nagrody) jest większa.

Według powyższych twierdzeń jednostki biorące udział w interakcjach szacują proporcjonalność uzyskiwanych nagród do ponoszonych kosztów i wnoszonych inwestycji własnych. 
Teoria wymiany społecznej spotkała się z krytyką ze strony różnych badaczy. Na przykład, Sabatelli i Shehan ${ }^{11}$ poddali ją krytyce za upraszczanie zachowań człowieka, wzorowanie się na modelu myślenia odpowiednim dla Skinnerowskich gołębi badanych w elementarnych sytuacjach, słowem za zbyt redukcjonistyczny charakter, właściwy dla klasycznego behawioryzmu. Została ona również uznana za niestabilną, bowiem pojęcia kosztów i nagród nie są jasno sprecyzowane. Jednakże pionierskie idee Homansa i innych teoretyków pobudziły kierunek badań w psychologii społecznej i do dziś jest on bardzo żywy, a uzyskane wyniki są w zasadzie trudne do zanegowania. Stąd też założona została w niniejszym opracowaniu ogólna przydatność tej teorii do wyjaśnienia komunikacji niewerbalnej towarzyszącej komunikacji werbalnej. W myśl tej teorii przyjęto założenie, zgodnie z którym całość wysiłku osób uczestniczących w procesie komunikacji zawiera się w podstawowym założeniu teorii wymiany społecznej scharakteryzowanym powyżej.

\section{Formy wymiany społecznej}

W związkach społecznych, zwłaszcza w procesie komunikacji, obustronna zależność nadawcy $(\mathrm{N})$ i odbiorcy $(\mathrm{O})$, może mieć charakter jednocześnie bezpośredni (gdzie $\mathrm{N}$ jest wartościowy dla $\mathrm{O}$ oraz $\mathrm{O}$ dla $\mathrm{N}$ ) lub pośredni, gdzie odbiorca korzyści nie odwzajemnia tych korzyści bezpośrednio, lecz czyni to wobec innego uczestnika biorącego udział w wymianie społecznej. Pierwszą zależność nazywam bezpośrednią wymianą społeczną, czyli wymianą aktów komunikacji, natomiast zależność pośrednią nazywam pośrednią wymianą społeczną. W niniejszym artykule, przyglądając się komunikacji niewerbalnej, skupiam się głównie na bezpośredniej wymianie społecznej i różnicach, jakie Blau, Emerson i Levi-Strauss odkryli między formami bezpośrednimi. Badacze ci podzielili te formy na „negocjowane” oraz „obustronne”. Terminy te definiuję poniżej.

a) wymiana negocjowana (ang. negotiated exchange). W wymianie negocjowanej uczestnicy (aktorzy) są zaangażowani w proces tworzenia wspólnych decyzji, w ramach których dochodzą do porozumienia. Proces ten wymaga zastosowania negocjacji. Obie strony wymiany dochodzą do porozumienia w tym samym czasie, a korzyści są z łatwością identyfikowane jako wkład, który tworzy transakcję. Przepływ korzyści w takiej wymianie jest dwustronny. Oznacza to, że żaden uczestnik (aktor) aktu komunikacji lub innego aktu wymiany społecznej

11 R. M. Sabatellii, C. Shehan, Exchange and resource theories, [w:] Sourcebook of family theories and methods: a contextual approach, P. G. Boss, W. J. Doherty, R. LaRossa, W. R. Schumm, S. K. Steinmetz (red.), New York 1993, s. 384-411. 
nie może otrzymać korzyści bez uprzedniego dojścia do porozumienia z drugą stroną. Na przykład, większość wymian ekonomicznych, a więc innych niż takie, gdzie z góry ustalone są ceny handlowe, pasuje do tej kategorii na równi z niektórymi wymianami społecznymi. W zależności od postawy interlokutorów wobec siebie oraz stylu komunikacyjnego negocjacja może być nastawiona na kooperację, gdzie interlokutorzy działają razem, aby osiągnąć wspólny cel, oraz na współzawodnictwo, gdzie interlokutorzy niejako „siłują" się ze sobą, aby osiągnąć ten sam cel. Jednakże współzawodnictwo dotyczy celu, którym może być określone zadanie komunikacyjne, a nie pokonywania drugiej strony.

b) wymiana obustronna (ang. reciprocal exchange). W wymianach obustronnych wkład aktorów w wymianę jest oddzielnie przedstawiony i nienegocjowalny. Uczestnicy tej formy interakcji rozpoczynają wymiany indywidualnie poprzez korzystne działanie dla drugiej strony wymiany. Może nim być np. udzielenie rady czy wyrażenie akceptacji. Działania te są wykonywane bez pewności odnośnie tego, czy i kiedy druga strona aktu komunikacyjnego odwzajemni włożony wkład. Ponieważ decyzje są podejmowane indywidualnie, koszty takiej wymiany są zazwyczaj jednostronne, ponieważ druga strona wymiany może, lecz nie musi wziąć udziału w wymianie. Jest to szczególnie ważne przy analizie wkładu komunikacyjnego ze strony nauczyciela, który jest w tym wypadku tą stroną wymiany, która - mniej czy bardziej świadomie - wnosi wkład do swojego udziału w komunikacji mając świadomość, że koszty są mimo wszystko jednostronne.

\section{Ocena wymiany społecznej przez jej uczestników}

Uczestnicy interakcji społecznej oceniają swoje zaangażowanie w interakcje (związki interakcyjne). To bowiem jednostki biorące udział w wymianie społecznej decydują o tym, czy wymianę społeczną kontynuować, czy też ją zakończyć. Thibaut i Kelly ${ }^{12}$ zaproponowali dwa standardy porównań, których używa się do oceny wyniku otrzymanego dzięki wymianie społecznej. Mają one charakter poznawczy. Są to:

- poziom porównawczy (PP, ang. comparison level),

- poziom porównawczy dla alternatyw $\left(\mathrm{PP}_{\mathrm{da}}\right.$, ang. comparison level for alternatives).

Poziom porównawczy odnosi się do relatywnej satysfakcji z istniejącej wymiany. Definiowany jest jako najniższy poziom wypłat uważanych za dodatnie. Poziom porównawczy jest - najogólniej mówiąc - średnią wartością wszystkich

12 H. H. Kelly, J. W. Thibaut, The social psychology... 
znanych jednostce bilansów, utworzoną z własnych doświadczeń interpersonalnych $\mathrm{w}$ przeszłości i obecnie porównywanych $\mathrm{z}$ bilansami u osób podobnych. Czynnik ten pozwala spoglądać na wynik wymiany interpersonalnej pod kątem treści wymiany: satysfakcjonujący/niesatysfakcjonujący. Kontakty satysfakcjonujące dają zysk (bilans) wyższy od oczekiwanego, kontakty niesatysfakcjonujące niższy, a więc oferują mniej, niż się człowiek spodziewa. Innym słowem, poziom porównawczy odnosi się do standardów reprezentujących to, co ludzie czują, i to, co powinni otrzymywać w procesie bilansowania nagród i kosztów w konkretnej interakcji społecznej. Dodać należy, iż typową miarą pozwalającą na określanie relacji w interakcjach społecznych jest indywidualne przeżycie z przeszłości danej jednostki biorącej udział w danej interakcji. Temu przeżyciu nadaje się znaczenie doświadczenia.

Poziom porównawczy dla alternatyw lepiej jest nazwać czynnikiem możliwości wyboru, gdyż tego bezpośrednio dotyczy. Jest to poziom satysfakcji (wartości bilansu), jaki spodziewa się uzyskać dana osoba we wszystkich aktualnie możliwych kontaktach; jest to przewidywana szansa na lepsze, bądź gorsze „wypłaty” (ang. „payoff”) związane z innymi znanymi lub nieznanymi jej osobami, biorącymi udział w interakcji. Im bardziej atrakcyjne możliwości zewnętrzne, będące poza związkiem interakcyjnym, stają się dostępne danej jednostce, lub jeżeli wynik działania $w$ danym zachowaniu interakcyjnym (relacji) spadnie poniżej alternatywnego poziomu porównawczego, niestabilność danej interakcji (aktu komunikacyjnego) zwiększa się. Zmiana partnera interakcyjnego łączy się z rozpoznaniem przez aktora zmniejszonego bilansu uzyskanych nagród. Jeżeli zatem możliwości zaistnienia innego kontaktu są korzystniejsze (zatem lepsze), to zależność od aktualnego partnera staje się względnie mała lub ustaje całkowicie. Jednym słowem, zmieniając partnera układu interakcyjnego można poprawić swój bilans. Oczywiście, nie jest to konieczne, jednak możliwość dokonania zmiany daje poczucie swobody i niezależności. Brzmi to bardziej jak analiza giełdowa aniżeli opis relacji międzyosobowej. Tak więc, nie dziwi fakt, iż autorzy teorii wymiany społecznej odnoszą się do niej również jako do "teorii zachowań ekonomicznych"13.

$\mathrm{Z}$ kolei inny przedstawiciel tej teorii, Roloff ${ }^{14}$, zaproponował pożyteczną typologię względnej wartości współzależności wyniku interakcji międzyosobowej, poziomu porównawczego i poziomu porównawczego dla alternatyw. Współzależności te przedstawia poniższa tabela (Tabela 1), która określa hierarchiczną sekwencję powyższych współzależności.

13 P. Blau, Exchange and power...; R. M. Emerson, Social exchange theory...

14 E. Roloff, Interpersonal communication: the social exchange approach, Beverly Hills 1981. 
Tabela 1. Związek pomiędzy PP, $\mathrm{PP}_{\mathrm{da}}$ a Wynikiem

(tabela zmodyfikowana przez autorkę, na podstawie Roloff ${ }^{15}$ ).

\begin{tabular}{|c|c|}
\hline I & II \\
\hline $\begin{array}{l}\text { Względna wartość współzależności } \\
\text { wyniku interakcji, poziomu } \\
\text { porównawczego i poziomu } \\
\text { porównawczego dla alternatyw: }\end{array}$ & $\begin{array}{l}\text { Stan relacji w interakcji międzyosobowej } \\
\text { (siła oddziaływania): }\end{array}$ \\
\hline $\begin{array}{l}\text { (a) } \\
\text { Wynik }>\mathrm{PP}_{\mathrm{da}}>\mathrm{PP}\end{array}$ & $\begin{array}{l}\text { Satysfakcjonujący } \\
\text { Stabilny } \\
\text { Niezależny }\end{array}$ \\
\hline $\begin{array}{l}\text { (b) } \\
\text { Wynik }>\mathrm{PP}>\mathrm{PP}_{\mathrm{da}}\end{array}$ & $\begin{array}{l}\text { Satysfakcjonujący } \\
\text { Stabilny } \\
\text { Zależny }\end{array}$ \\
\hline $\begin{array}{l}\text { (c) } \\
\mathrm{PP}_{\mathrm{da}}>\mathrm{PP}>\text { Wynik }\end{array}$ & $\begin{array}{l}\text { Niesatysfakcjonujący } \\
\text { Niestabilny } \\
\text { Zakończ relację i szukaj satysfakcji } \\
\text { w innej relacji }\end{array}$ \\
\hline $\begin{array}{l}(\mathrm{d}) \\
\mathrm{PP}_{\mathrm{da}}>\text { Wynik }>\mathrm{PP}\end{array}$ & $\begin{array}{l}\text { Satysfakcjonujący } \\
\text { Niestabilny } \\
\text { Szczęśliwy poza relacją } \\
\end{array}$ \\
\hline $\begin{array}{l}\text { (e) } \\
\mathrm{PP}>\mathrm{PP}_{\mathrm{da}}>\text { Wynik }\end{array}$ & $\begin{array}{l}\text { Niesatysfakcjonujący } \\
\text { Niestabilny } \\
\text { Nieszczęśliwy }\end{array}$ \\
\hline $\begin{array}{l}\text { (f) } \\
\mathrm{PP}>\text { Wynik }>\mathrm{PP}_{\mathrm{da}}\end{array}$ & $\begin{array}{l}\text { Wysoce niesatysfakcjonujący lecz stabilny } \\
\text { Nie możesz zakończyć relacji } \\
\text { Zależny i nieszczęśliwy }\end{array}$ \\
\hline
\end{tabular}

Z powyższej tabeli wynika jednoznacznie, że najbardziej optymistyczna względna wartość współzależności to wartość uwzględniona w wariancie (a), obejmująca parametry: satysfakcjonujący, stabilny, niezależny. Wariant (a) stanowić zatem może punkt docelowy każdego typu interakcji, w tym również szczególnego typu interakcji, jaką jest np. interakcja komunikacyjna nauczyciel - uczeń. Tak więc poziom oczekiwań w porównaniu z uzyskiwanym bilansem decyduje o zadowoleniu bądź niezadowoleniu (a więc o wymiarze satysfakcji), zaś postrzeganie możliwości wyboru wskazuje na stopień zależności od partnera. Satysfakcja i zależność (tj. kontrola zachowań) to dwa podstawowe wymiary kontaktu interpersonalnego.

15 Ibidem. 
W nawiązaniu do różnic w atrakcyjności oraz stabilności typów relacji społecznych powyższa tabela może stanowić podstawę do rozróżniania typów związków na podstawie tzw. „siły oddziaływania” (ang. power), która wynika pośrednio z relacji pomiędzy domenami I i II (patrz Tabela 1). I tak, gdy Wynik wyprzedza $\mathrm{w}$ dużym stopniu poziom porównawczy dla alternatyw $\left(\mathrm{PP}_{\mathrm{da}}\right)$, wtedy niezależność jednostki od uczestników interakcji jest największa a siła oddziaływania najmniejsza. Określa ten słaby stopień oddziaływania obecność parametru „niezależny” w Tabeli 1 (pozycja (a)). Natomiast, gdy Wynik wyprzedza bezpośrednio $\mathrm{PP}_{\mathrm{da}}$, wtedy zależność jednostki od uczestników interakcji jest największa. Określa ten silny stopień oddziaływania obecność parametru „zależny” w Tabeli 1 (pozycja (b)).

Thibaut i Kelly ${ }^{16}$ nie zastanawiają się jednak, czy jest to dobry, czy zły znak. W głównej mierze zwracają oni uwagę na połączenie między zależnością a kontrolą. Ich stanowisko względem siły oddziaływania oparte jest na zaangażowaniu trzech różnych form kontroli. Są to:

1. Kontrola zwrotna (ang. reflexive control): jest to umiejętność nagradzania siebie samego.

2. Kontrola bezwzględna (ang. fate control): jest to umiejętność wpływania jednostki na partnera bez względu na to, co robi. Tutaj możemy rozróżnić:

a) kontrolę środowiskową, (ang. environmental fate control),

b) kontrolę wzajemną (ang. mutual fate control).

3. Kontrola zachowania (ang. behavior control): jest to umiejętność, którą ludzie posiadają i stosują, aby zmienić zachowanie innych przez zmianę swojego zachowania. Uczestnicy wymiany społecznej, pozostający w związku o charakterze współzależności, zazwyczaj operują trzema wyżej wspomnianymi typami kontroli jednocześnie.

\section{Komunikacja niewerbalna w ujęciu teorii wymiany społecznej}

W ujęciu teorii wymiany społecznej:

1. Zakłada się, że w wymianie społecznej bierze również udział komunikacja niewerbalna, która posiadać może wymiar pozytywny lub/i negatywny. Wymiary te rozpatrywane są w kategoriach uniwersalnych (globalnych) uczuć interlokutorów. 
I tak, wymiar pozytywny angażuje uczucia radości, entuzjazmu, ekscytacji, a przede wszystkim - zainteresowanie udziałem w komunikacji. Wymiar negatywny natomiast angażuje uczucia smutku, niezadowolenia, budzi napięcia, a także powoduje brak zainteresowania dalszym udziałem w komunikacji.

2. Zakłada się, że komunikacja niewerbalna w wymianie społecznej zawiera w sobie bodźce „nagradzające” lub/i „karzące”. Bodźce te dana jednostka odbiera lub nadaje w zależności od ogólnego kontekstu komunikacyjnego, a także w zależności od własnej świadomości odnośnie ich siły oddziaływania.

3. Ponadto zakłada się, że uczestnicy biorący udział w wymianie społecznej dążą do komfortu psychicznego poprzez pozytywne zachowania niewerbalne, czyli tzw. „bezpośredniość niewerbalną” (ang. nonverbal immediacy) $)^{17}$.

\section{Wymiana (interakcja) społeczna w ujęciu teorii wpływu społecznego}

Teoria wpływu społecznego sformułowana została na gruncie psychologii pod koniec lat trzydziestych XX w. wraz z rozwojem teorii pola (ang. field theory), którą zaproponował niemiecki psycholog, Kurt Lewin ${ }^{18}$. Teoria ta zakładała, że człowiek jest podmiotem wyodrębnionym z otoczenia i jednocześnie jest także elementem większej całości (np. ekologicznej, społecznej). Oznacza to, że zachowania poszczególnych jednostek dokonują się w trakcie procesu interakcyjnego człowiek - otoczenie społeczne ${ }^{19}$. Teoria ta wydaje się obecnie zupełnie oczywista, lecz na początku XX w. psychologia nie w pełni przyjęła behawioryzm, a jedyną akceptowaną teorią psychologiczną owych czasów była psychoanaliza ${ }^{20}$. Zakładała ona, iż treścią ludzkiej nieświadomości są wyparte ze świadomości motywy. Lewin natomiast zakładał, iż motywami są siły ukierunkowane na cel. Zakładał on, „że nasze zachowanie jest celowe; żyjemy w rzeczywistości psychologicznej

17 J. Puppel, Bezpośredniość niewerbalna a efektywność nauczyciela języka obcego, [w:] Wokół języka i kultury - studia interdyscyplinarne, H. Lankiewicz (red.), Piła 2009, s. 41-50.

18 K. Lewin, Defining the "field at a given time”, „Psychological Review” 1943, nr 50, s. 292-310; K. Lewin, Field theory in social science, New York 1951.

19 T. Tomaszewski, Wstęp do psychologii, Warszawa 1963; J. Strelau (red.), Psychologia. Podręcznik akademicki. Vol. 1: Podstawy psychologii, Gdańsk 2000.

20 S. Freud (red. przez J. Stackey, A. Freud), The standard edition of complete psychological works of Sigmund Freud. 24 vols, London 1953-1974. 
bądź przestrzeni życiowej, która włącza nie tylko te części ważne dla naszego fizycznego i społecznego środowiska, lecz także wyimaginowane stany, które obecnie nie mają miejsca" ${ }^{21}$.

Teoria pola miała ogromny wpływ na rozwój współczesnej psychologii społecznej. W literaturze przedmiotu znaleźć można wiele definicji psychologii społecznej. Niemniej jednak warto przytoczyć definicję Domachowskiego ${ }^{22}$, która przedstawia psychologię społeczną jako naukę odnoszącą się do prawidłowości funkcjonowania człowieka jako jednostki i jednocześnie jako naukę o postrzeganiu człowieka jako jednostki i która to jednostka nawiązuje określone stosunki z innymi członkami danej społeczności. Moscovici² ${ }^{23}$, wspominając o psychologii społecznej, wymienia takie zjawiska jak: postawy, grupy, stosunki, uprzedzenia i postrzegania społeczne. I to, co jest w nich wspólne to przedmiot badań omawianej dziedziny, czyli wpływ (oddziaływanie) społeczny. Jest to wpływ, jaki wywierają ludzie na poglądy i zachowania innych ludzi. Spędzając wiele czasu na kontaktach z innymi ludźmi, formułujemy własne hipotezy na temat zachowań społecznych, co pomaga nam zrozumieć na przykład, dlaczego pewne osoby odbieramy pozytywnie, inne zaś negatywnie. Wyniki naszych własnych intuicyjnych obserwacji często pokrywają się z rezultatami badań eksperymentalnych prowadzonych przez psychologów społecznych w ramach proponowanych przez nich teorii. W tym kontekście teoria wpływu społecznego (ang. the social impact theory) bada, jak obecność innych uczestników interakcji wpływa na ludzkie zachowania. Teorię tę jako pierwszy zdefiniował Bibb Latané ${ }^{4}$. Zakłada ona, iż na wpływ społeczny wystawiona jest każda jednostka uczestnicząca w akcie komunikacyjnym, a wpływ ten zależy od liczby osób zaangażowanych w interakcję, od statusu społecznego osób, oraz jak blisko znajdują się one w czasie i przestrzeni od jednostki, która jest celem wpływu społecznego.

Teoria zaprezentowana przez Latané ${ }^{25}$ sprowadza się do trzech zasad rządzących interakcjami. Są to następujące zasady, zwane tutaj zasadami interakcyjnymi $(\mathrm{ZI})$ :

21 Gdzie fragment ten w oryginale brzmi: ,that our behavior is purposeful; we live in a psychological reality or life space that includes not only those parts of our physical and social environment that are important to us but also imagined states that do not currently exist" (za: D. M. Mayton II, Nonviolence and peace psychology, London - New York 2009, s. 205 (tłumaczenie J. P.).

22 W. Domachowski, Psychologia społeczna komunikacji niewerbalnej, Toruń 1993; W. Domachowski, Przewodnik po psychologii społecznej, Warszawa 1999.

23 S. Moscovici, Wplywy świadome i wplywy nieświadome, [w:] Psychologia społeczna w relacji ja inni, S. Moscovici (red.), Warszawa 1998, s. 123-139.

24 B. Latané, The psychology of social impact, „American Psychologist” 1981, nr 136, s. 343-356.

25 Ibidem. 
ZI 1: Im więcej uczestników bierze udział w interakcji, tym większy wpływ mają oni na poszczególnych interlokutorów (aktorów). Ponadto, im większą rolę społeczną odgrywają poszczególne jednostki, tym większy wpływ mają te osoby na swoich odbiorców (np. w diadzie nauczyciel $\rightarrow$ uczeń, będącej częścią układu komunikacyjnego nauczyciel - uczniowie, większy wpływ powinien mieć nauczyciel).

ZI 2: Wpływ innych na jednostkę zwiększa się wraz ze wzrostem liczby uczestników aktu komunikacyjnego. W świetle pierwszej zasady obecna zasada zdaje się mieć rankingowo mniejsze zastosowanie w warunkach układu komunikacyjnego nauczyciel - uczniowie w klasie. Zasadę tę ilustruje poniższy schemat:

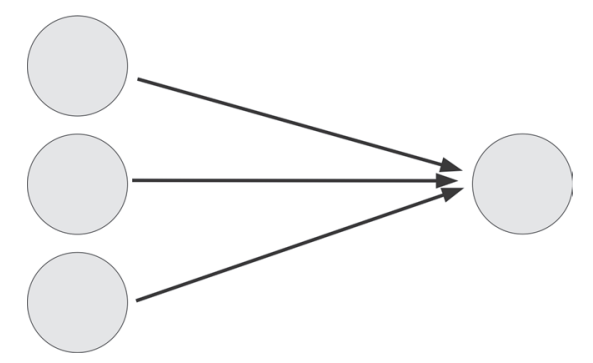

Schemat 1

ZI 3: Każdy uczestnik aktu komunikacyjnego może wpłynąć na innych, lecz im większa jest liczba osób, tym mniejszy wpływ będzie miał poszczególny uczestnik tego aktu. Dlatego też jesteśmy bardziej skłonni słuchać jednego komunikatora, jeżeli jesteśmy w mniejszej grupie aniżeli w większej. Zasadę tę ilustruje poniższy schemat:

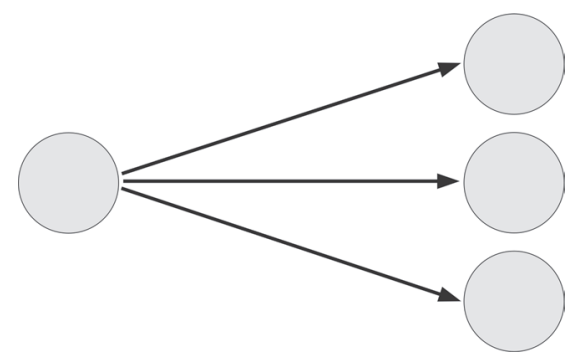

Schemat 2

Oczywistym jest, że powyższe Zasady mają istotne znaczenie dla konkretnego układu komunikacyjnego 'nauczyciel - uczniowie' w klasie w sensie przyznania nauczycielowi takiego właśnie statusu osoby, której w takim układzie skłonni jesteśmy słuchać bardziej. W myśl tych zasad nauczyciel powinien zachować się 
w odpowiedni sposób, tj. poprzez zwiększenie wyrazistości swojego udziału w aktach komunikacyjnych, zabiegać o zwiększenie swego wpływu na środowisko swoich interlokutorów. Jednym ze sposobów jest nasycenie aktów komunikacyjnych ze strony nauczyciela świadomie wybranymi elementami komunikacji niewerbalnej na zasadzie ich zwiększonego udziału w interakcji celem uzyskania lepszego bilansu. Mówiąc inaczej, większy wkład elementów komunikacji niewerbalnej do aktu komunikacji zwiększa wyrazistość nauczania i tym samym zwiększa prawdopodobieństwo lepszego „poboru” treści nauczania przez uczniów.

Wyżej wymieniona teoria spotkała się z zainteresowaniem ze strony psychologów społecznych i jest przez nich ciągle testowana ${ }^{26}$. W niniejszym artykule główne założenia teorii wymiany społecznej wymienione w Zasadach Interakcyjnych (ZI 1 - ZI 3) mogą posłużyć do wyjaśnienia, chociażby zachowań niewerbalnych zachodzących w układzie komunikacyjnym nauczyciel - uczniowie, tj. w komunikacji dydaktycznej jako szczególnym przejawie procesu komunikacji.

\section{Komunikacja niewerbalna w ujęciu teorii wpływów społecznych}

Komunikacja niewerbalna ma ogromny wpływ zarówno na recepcję osób biorących udział w procesie komunikacyjnym jak również na przekaz informacji. Zazwyczaj jest to proces nieintencjonalny, a tym samym nieuświadomiony. W sytuacji klasowej np. użycie komunikatów niewerbalnych powinno być procesem racjonalnym, a więc świadomym, głównie ze strony nauczyciela. Wiemy, że wpływ społeczny jest procesem wzajemnym. Tak więc obie strony aktu komunikacyjnego poprzez użycie komunikatów niewerbalnych wpływają na siebie.

Klasyczne już dziś badania przedstawione przez Mehrabiana ${ }^{27}$ wykazały, iż tylko 7\% informacji całego przekazu zawarte jest w materiale werbalnym (słowach), 38\% w tonie głosu oraz innych wskaźnikach wokalnych, natomiast aż $55 \%$ informacji przekazywanej jest za pomocą środków niewerbalnych. Podobne badania przeprowadził Birdwhistell ${ }^{28}$, który spostrzegł, iż udział strony werbalnej w interakcji społecznej wynosi mniej niż 35\%, a ponad 65\% znaczenia komunikatu przekazywane jest za pomocą komunikacji niewerbalnej.

W świetle powyższych danych nie ulega wątpliwości, że komunikacja niewerbalna stanowi istotny element każdego aktu komunikacyjnego, w tym - oczywi-

26 K. Deaux, L. S. Wrightsman, Social psychology, Pacific Grove 1988; A. Tesser, Advanced social psychology, New York 1995.

27 A. Mehrabian, Nonverbal communication, New Brunswick - London 1972 (2007).

28 R. L. Birdwhistell, Kinesics and context. Essays on body motion communication, Philadelphia 1970. 
ście - aktów komunikacyjnych mających miejsce w sformalizowanych warunkach klasy, a więc również w odniesieniu do tych, które dotyczą np. nauczania języka obcego.

\section{Podsumowanie}

W niniejszym artykule przedstawiono główne założenia Teorii Wymiany Społecznej i Teorii Wpływu Społecznego. Obydwie teorie pozwalają na analizę aktów komunikacyjnych zarówno od strony zysków i kosztów, jak i od strony intensywności wpływu danej jednostki na inną w interakcjach społecznych. Przedstawiona tu dyskusja pozwala sformułować następujące zasady rządzące komunikacją niewerbalną w ujęciu obydwu Teorii. Zasady te są hierarchiczne w stosunku do Zasad Interakcyjnych (ZI) omówionych powyżej. Zasady te, zwane tutaj zasadami komunikacji niewerbalnej (ZKN), sformułowane zostały następująco:

ZKN 1: Każde zachowanie niewerbalne wpływa na uczestników aktu komunikacyjnego w sposób mniej lub bardziej pozytywny.

ZKN 2: Im więcej pozytywnych elementów niewerbalnych towarzyszy przekazowi werbalnemu (czyli niejako dopełnia komunikat), tym skuteczniejszy jest ten przekaz i tym samym ma on większy wpływ na poszczególnych uczestników aktu komunikacyjnego.

ZKN 3: Jesteśmy skłonni słuchać tych komunikatorów, którzy operują pozytywnymi zachowaniami niewerbalnymi, o charakterze bezpośredniości.

ZKN 4: Jesteśmy skłonni słuchać tych komunikatorów, których siła oddziaływania jest największa.

ZKN 5: Jesteśmy skłonni sami osiągnąć status komunikatora o możliwie największej sile oddziaływania.

Z punktu widzenia teorii wymiany społecznej oraz teorii wpływu społecznego układ komunikacyjny postrzegany jest jako proces wzajemnej zależności i oddziaływania, w którym uczestnicy zależą od siebie celem osiągnięcia zysku w postaci dwustronnej satysfakcji, np. osiągnięcia sukcesu w nauczaniu ze strony nauczyciela oraz osiągnięcia sukcesu w formie efektywnego uczenia się ze strony ucznia. Każdy komunikator uczestniczący w swoistej wymianie społecznej, jaką jest niewątpliwie komunikacja werbalna i niewerbalna, wpływają na siebie w taki sposób, iż komunikacja niewerbalna wzmacnia komunikat werbalny. Również wpływ ten pozwala z kolei zorientować się co do skuteczności przekazu i recepcji.

Bardzo wyraźnie widać na podstawie powyżej sformułowanych zasad komunikacji niewerbalnej, iż wkład uczestników aktu komunikacyjnego w odniesieniu do użycia elementów komunikacji niewerbalnej jest odpowiednio przez nich war- 
tościowany, tj. elementy te dają się uporządkować w odpowiedni ranking na osi „pozytywny” (przyjemny) - „negatywny” (nieprzyjemny). Tym samym zwiększona liczba pozytywnych elementów komunikacji niewerbalnej stanowi te wartości aktu komunikacyjnego, które w wyraźny sposób prowadzą do osiągnięcia sukcesu w komunikacji oraz do akceptacji komunikatorów.

\section{Literatura}

Bandura A., Social Learning Theory, New York 1977.

Birdwhistell R. L., Kinesics and context. Essays on body motion communication, Philadelphia 1970. Blau P., Exchange and power in social life, New York 1964.

Deaux K., Wrightsman L. S., Social psychology, Pacific Grove 1988.

Domachowski W., Psychologia społeczna komunikacji niewerbalnej, Toruń 1993.

Domachowski W., Przewodnik po psychologii społecznej, Warszawa 1999.

Emerson R. M., Social exchange theory, „American Sociological Review” 1976, nr 35, s. 335-362.

Freud S., (red. przez J. Stackey i A. Freud). The standard edition of complete psychological works of Sigmund Freud, 24 vols., London 1953-1974.

Homans G., Social behavior: its elementary forms, New York 1961 (1972).

Kelly H. H., Personal relationships: their structures and processes, Hillsdale 1979.

Kelly H. H., Thibaut J. W., The social psychology of groups, New York 1959.

Kelly H. H., Thibaut J. W., Interpersonal relationships, New York 1978.

Latane B., The psychology of social impact, „American Psychologist” 1981, nr 36, s. 343-356.

Lewin K., Defining the “field at a given time”, „Psychological Review” 1943, nr 50, s. 292-310.

Lewin K., Field theory in social science, New York 1951.

Levi-Strauss C., The elementary structures of kinship, Boston 1969.

Mayton II D. M., Nonviolence and peace psychology, London and New York 2009.

Mehrabian A., Nonverbal communication, New Brunswick - London 1972 (2007).

Moscovici S., Wplywy świadome i wplywy nieświadome, [w:] Psychologia społeczna w relacji ja inni, S. Moscovici (red.), Warszawa 1998, s. 123-139.

Mill J. S., Principles of Political Economy with Some of their Applications to Social Philosophy, London 1848.

Puppel J., Bezpośredniość niewerbalna a efektywność nauczyciela języka obcego, [w:] Wokół języka $i$ kultury - studia interdyscyplinarne, H. Lankiewicz (red.), Piła 2009, s. 41-50.

Roloff E., Interpersonal communication: the social exchange approach, Beverly Hills 1981.

Sabatelli R. M., Shehan C., Exchange and resource theories, [w:] Sourcebook of family theories and methods: a contextual approach, P. G. Boss, W. J. Doherty, R. LaRossa, W. R. Schumm, S. K. Steinmetz (red.), New York 1993, s. 384-411.

Skinner B. F., Verbal behavior, Massachusetts 1957.

Strelau J. (red.), Psychologia. Podręcznik akademicki. Vol. 1: Podstawy psychologii, Gdańsk 2000.

Strelau J. (red.), Psychologia. Podręcznik akademicki. Vol. 2: Psychologia ogólna, Gdańsk 2000.

Tesser A., Advanced social psychology, New York 1995.

Tomaszewski T., Wstęp do psychologii, Warszawa 1963. 